\title{
Mefloquine-Oxazolidine Derivatives: A New Class of Anticancer Agents
}

Felipe A. R. Rodrigues ${ }^{1}$, Igor da S. Bomfim ${ }^{1}$, Bruno C. Cavalcanti ${ }^{1}$, Claudia Pessoa ${ }^{1}$, Raoni S. B. Goncalves ${ }^{2}$, James L. Wardell ${ }^{2,3}$, Solange M. S. V. Wardell ${ }^{4}$ and Marcus V. N. de Souza ${ }^{2, *}$

${ }^{1}$ Laboratório de Oncologia Experimental, Universidade Federal do Ceará, Fortaleza, CE 3157, Brazil

${ }^{2}$ FioCruz-Fundação Oswaldo Cruz, Instituto de Tecnologia em Fármacos-Far-Manguinhos, Rua Sizenando Nabuco, 100, Manguinhos, 21041-250, Rio de Janeiro, RJ 35513, Brazil

${ }^{3}$ Department of Chemistry, University of Aberdeen, Old Aberdeem, Aberdeem, AB 24 3UE, UK

${ }^{4}$ CHEMSOL, 1 Harcourt Road, Aberdeen, AB15 5NY, UK ${ }^{*}$ Corresponding author: Marcus V. N. de Souza, marcos_souza@far.fiocruz.br

\begin{abstract}
A series of 23 racemic mefloquine-oxazolidine derivatives, 4-[3-(aryl)hexahydro[1,3]oxazolo[3,4-a]pyridin1-yl]-2,8-bis(trifluoromethyl)quinolines, derived from $\left(R^{*}, \mathrm{~S}^{*}\right)-( \pm)$-mefloquine and arenealdehydes, have been evaluated for their activity against four cancer cell lines (HCT-8, OVCAR-8, HL-60, and SF-295). Good cytotoxicities have been determined with $\mathrm{IC}_{50}$ values ranging from 0.59 to $4.79 \mu \mathrm{g} / \mathrm{mL}$. In general compounds with aryl groups having strong electron-releasing substituents, such as $\mathrm{HO}$ and $\mathrm{MeO}$, or electron-rich heteroaryl groups, for example imidazol-2-y-I, are active. However, other factors such as steric effects may play a role. As both the active and non-active conformations of the mefloquine-oxazolidine derivatives are similar, it is concluded that molecular conformations do not play a significant role either. This study is the first to evaluate mefloquine derivatives as antitumor agents. The mefloquine-oxazolidine derivatives are considered to be useful leads for the rational design of new antitumor agents.
\end{abstract}

Key words: anticancer, antitumor activity, mefloquine, oxazolidine

Received 15 April 2013, revised 16 June 2013 and accepted for publication 12 August 2013

Mefloquine (MQ), $\left(R^{*}, \mathrm{~S}^{*}\right)-( \pm)$ - $\alpha$-2-piperidinyl-2,8-bis(trifluoromethyl)-4-quinolinemethanol, also known as Lariam, Mephaquin, or Mefliam, is an important drug orally administrated in the prevention and treatment of malaria. However, in the last years, this drug has been found to have promising applications in other fields, such as against Gram-positive and Gram-negative bacteria (1), in particular against Mycobacterium tuberculosis (2,3) and Mycobacterium avium complex (MAC) $(4,5)$ and also against schistosomiasis (6), neurodegenerative, and (neuro-) inflammatory diseases (7). A clear indication of the promise of this drug in fields other than malaria is the number of recent patent applications $(5,7,8)$. More recently, much attention has been paid to the potential perspectives of $\mathrm{MQ}$ as an anticancer agent. As estimated by the National Institutes of Health $(\mathrm{NIH})$, the overall costs of cancer in 2007 were $\$ 226.8$ billion. ${ }^{a}$ Cancer is a leading cause of deaths worldwide and accounted for 7.6 million deaths (13\% of all deaths) in 2008. ${ }^{\mathrm{b}}$ Louie and coworkers (9) found $\mathrm{MQ}$ to be the most potent anticancer drug when compared to chloroquine and the fluoroquinolone drugs cipro and levofloxacin. $M Q$ inhibits autophagy and triggered endoplasmic reticulum stress. It also causes cell death in T47D and MDAMB-231. Cho and coworkers also investigated the effect of autophagy on mefloquinemediated cytotoxicity in neuroblastoma cells (10).

To study the potential of $M Q$ analogues as anticancer agents, it is necessary to develop and evaluate $M Q$ derivatives. Prime goals are to enhance the effectiveness and to minimize side-effects, as well as to provide a better understanding of the mechanism of action. In this work, we present the results of the evaluation of a series of twentythree mefloquine-oxazolidine derivatives (Scheme 1) against several cancer cell lines, including HCT-8, OVCAR-8, HL-60 and SF-295. The results are very promising, as exemplified in Tables 1 and 2.

\section{Methods and Materials}

\section{Cytotoxicity assays}

Cytotoxicity against cancer cell lines

Compounds 1a-s, 2a-c, 3 and $\mathbf{M Q}(0.009-5 \mu \mathrm{g} / \mathrm{mL})$ were tested for their cytotoxic activity against 3-5 cancer cell lines: SF-295 (nervous system), HCT-116 (colon), OVCAR8 (ovarium), HCT-8 (colon), and HL60 (leukemia) (National Cancer Institute, Bethesda, MD, USA). All cell lines were maintained in RPMI 1640 medium supplemented with 10\% fetal bovine serum, $2 \mathrm{~mm}$ glutamine, $100 \mathrm{U} / \mathrm{mL}$ penicillin, and $100 \mu \mathrm{g} / \mathrm{mL}$ streptomycin at $37{ }^{\circ} \mathrm{C}$ with $5 \% \mathrm{CO}_{2}$. Each compound was dissolved in DMSO to give a concentration 


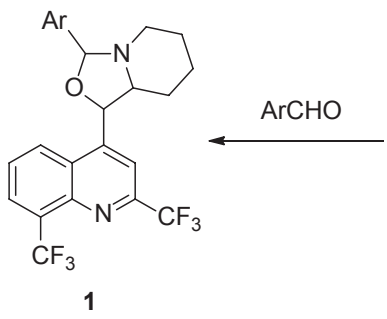<smiles>OC(c1cc(C(F)(F)F)nc2c(C(F)(F)F)cccc12)C1CCCCN1</smiles>

Mefloquine<smiles>[R]c1c[Y]c(CO)c1CO</smiles><smiles>[R]C1=C[Y]C(C2OC(c3cc(C(F)(F)F)nc4c(C(F)(F)F)cccc34)C3CCCCN32)[X]1</smiles>

2

Scheme 1: Synthesis of

mefloquine-oxazolidine derivatives.<smiles>O=Cc1ccc(C=O)cc1</smiles>

Table 1: Growth inhibition percentage (GI\%) for three tumor cell lines ${ }^{a}$, measured by MTT assay

\begin{tabular}{|c|c|c|c|c|c|c|c|}
\hline \multicolumn{2}{|c|}{ Entry } & \multirow{2}{*}{$\frac{\text { SF-295 }}{\text { Gl\% }}$} & \multirow[b]{2}{*}{ SD\% } & \multirow{2}{*}{$\frac{\mathrm{HCT}-116}{\mathrm{GI} \%}$} & \multirow[b]{2}{*}{ SD\% } & \multirow{2}{*}{$\frac{\text { OVCAR-8 }}{\text { Gl\% }}$} & \multirow[b]{2}{*}{ SD\% } \\
\hline No & Ar or heteroaryl & & & & & & \\
\hline $1 a$ & $\mathrm{C}_{6} \mathrm{H}_{5}$ & 33.74 & 0.46 & 56.74 & 3.85 & 43.52 & 4.33 \\
\hline $1 b$ & $2-\mathrm{HOC}_{6} \mathrm{H}_{4}$ & 100.88 & 0.06 & 100.82 & 0.27 & 101.44 & 0.00 \\
\hline $1 c$ & 2- $\mathrm{MeOC}_{6} \mathrm{H}_{4}$ & 53.80 & 1.90 & 94.81 & 3.04 & 100.78 & 0.31 \\
\hline $1 d$ & $4-\mathrm{MeOC}_{6} \mathrm{H}_{4}$ & 31.84 & 8.89 & 71.09 & 2.06 & 21.68 & 14.34 \\
\hline $1 e$ & $3,4-(\mathrm{MeO})_{2} \mathrm{C}_{6} \mathrm{H}_{3}$ & 46.55 & 9.45 & 100.30 & 0.85 & 100.29 & 0.58 \\
\hline $1 f$ & $3,4,5-(\mathrm{MeO})_{3} \mathrm{C}_{6} \mathrm{H}_{2}$ & 36.80 & 5.71 & 52.78 & 5.94 & 21.55 & 1.23 \\
\hline $1 \mathrm{~g}$ & $3-\mathrm{EtOC}_{6} \mathrm{H}_{4}$ & 34.69 & 8.06 & 24.40 & 59.49 & 8.99 & 13.64 \\
\hline $1 \mathrm{~h}$ & $4-\mathrm{FC}_{6} \mathrm{H}_{4}$ & 32.89 & 0.77 & 39.78 & 0.18 & 31.33 & 1.65 \\
\hline $1 \mathrm{i}$ & $2-\mathrm{ClC}_{6} \mathrm{H}_{4}$ & 22.28 & 0.59 & 40.09 & 38.92 & 12.26 & 4.78 \\
\hline $1 \mathrm{j}$ & $3-\mathrm{ClC}_{6} \mathrm{H}_{4}$ & 33.50 & 6.73 & 27.84 & 13.76 & 26.20 & 3.56 \\
\hline $1 \mathrm{k}$ & $4-\mathrm{ClC}_{6} \mathrm{H}_{4}$ & 80.38 & 28.93 & 101.58 & 0.45 & 101.16 & 0.08 \\
\hline 11 & $2,3-\mathrm{Cl}_{-2} \mathrm{C}_{6} \mathrm{H}_{3}$ & 24.94 & 3.10 & 40.28 & 3.41 & 8.50 & 0.41 \\
\hline $1 \mathrm{~m}$ & $2,4-\mathrm{Cl}_{2} \mathrm{C}_{6} \mathrm{H}_{3}$ & 17.41 & 8.42 & 19.70 & 1.39 & -17.58 & 7.63 \\
\hline $1 n$ & $3,4-\mathrm{Cl}_{2} \mathrm{C}_{6} \mathrm{H}_{3}$ & 20.39 & 14.64 & 23.58 & 1.43 & 12.04 & 2.74 \\
\hline 10 & $3-\mathrm{BrC}_{6} \mathrm{H}_{4}$ & 34.50 & 4.56 & 42.02 & 3.95 & 36.17 & 12.52 \\
\hline $1 p$ & $4-\mathrm{BrC}_{6} \mathrm{H}_{4}$ & 38.13 & 9.01 & 53.95 & 0.18 & 20.85 & 7.68 \\
\hline $1 q$ & $2-\mathrm{O}_{2} \mathrm{NC}_{6} \mathrm{H}_{4}$ & 22.56 & 22.32 & 23.77 & 48.30 & 23.56 & 3.48 \\
\hline $1 \mathrm{r}$ & $3-\mathrm{O}_{2} \mathrm{NC}_{6} \mathrm{H}_{4}$ & 30.89 & 1.74 & 32.29 & 0.43 & 11.96 & 17.24 \\
\hline $1 \mathrm{~s}$ & $4-\mathrm{O}_{2} \mathrm{NC}_{6} \mathrm{H}_{4}$ & 29.12 & 21.72 & 61.47 & 2.24 & 18.70 & 2.74 \\
\hline $2 a$ & $5-\mathrm{O}_{2} \mathrm{~N}$-furan-2-yl & 37.80 & 4.45 & 14.42 & 0.32 & 10.38 & 23.13 \\
\hline $2 b$ & $5-\mathrm{O}_{2} \mathrm{~N}$-thien-2-yl & 14.14 & 3.86 & 18.99 & 6.64 & 26.41 & 4.99 \\
\hline $2 c$ & Imidazol-2-yl & 29.91 & 3.68 & 84.82 & 12.70 & 97.51 & 0.08 \\
\hline 3 & - & 37.11 & 5.00 & -0.66 & 4.37 & -6.62 & 0.25 \\
\hline- & Mefloquine & 98.44 & 2.42 & 101.93 & 1.36 & 99.93 & 0.46 \\
\hline
\end{tabular}

${ }^{a}$ Cell lines: nervous system (SF-295), colon (HCT-116), and ovarium (OVCAR-8).

of $1 \mathrm{mg} / \mathrm{mL}$. The final concentration of DMSO in the culture medium was kept below $0.1 \%(\mathrm{v} / \mathrm{v})$. Compounds $\mathbf{1 a}-\mathbf{s}$,

2a-c, 3, and $M Q$ were incubated with the cells for $72 \mathrm{~h}$. The negative control received the same amount of DMSO
( $0.001 \%$ in the highest concentration). The cell viability was determined by reduction in the yellow dye 3-(4,5-dimethyl2-thiazol)-2,5-diphenyl-2H-tetrazolium bromide (MTT) to a blue formazan product as described by Mosmann (11). 
Rodrigues et al.

Table 2: Cytotoxic activity of mefloquine-oxazolidine derivatives $1 \mathrm{~b}-\mathrm{e}$ and 2 on Tumor Cell Lines ${ }^{\mathrm{a}}$

\begin{tabular}{|c|c|c|c|c|c|}
\hline \multicolumn{3}{|c|}{ Entry } & \multicolumn{3}{|l|}{$\mathrm{IC}_{50}(\mu \mathrm{g} / \mathrm{mL})$} \\
\hline No & Ar or heteroaryl & HCT-8 & OVCAR-8 & HL-60 & SF-295 \\
\hline \multirow[t]{2}{*}{$1 b$} & $2-\mathrm{HOC}_{6} \mathrm{H}_{4}$ & 2.699 & 2.824 & 3.338 & 1.606 \\
\hline & & $2.320-3.140$ & $2.346-3.400$ & $2.186-5.098$ & $0.9841-2.621$ \\
\hline \multirow[t]{2}{*}{$1 c$} & 2- $\mathrm{MeOC}_{6} \mathrm{H}_{4}$ & 2.957 & 4.074 & 3.635 & 4.785 \\
\hline & & $2.657-3.291$ & $3.304-5.023$ & $2.606-5.070$ & $2.833-8.082$ \\
\hline \multirow[t]{2}{*}{$1 d$} & 4- $\mathrm{MeOC}_{6} \mathrm{H}_{4}$ & 1.514 & 0.9450 & 1.913 & 3.598 \\
\hline & & $1.251-1.831$ & $0.5600-1.595$ & $1.498-2.444$ & $3.299-3.925$ \\
\hline \multirow[t]{2}{*}{$1 e$} & $3,4-(\mathrm{MeO})_{2} \mathrm{C}_{6} \mathrm{H}_{3}$ & 3.077 & 2.839 & 2.343 & 3.250 \\
\hline & & $2.359-4.012$ & $1.041-7.738$ & $2.101-2.613$ & $2.519-4.194$ \\
\hline \multirow[t]{2}{*}{$1 k$} & 4- $\mathrm{Cl} \mathrm{C}_{6} \mathrm{H}_{4}$ & 2.957 & 4.074 & 0.8873 & 3.524 \\
\hline & & 2.658-3.291 & $3.304-5.023$ & $0.4072-1.934$ & $3.049-4.072$ \\
\hline \multirow[t]{6}{*}{$2 c$} & Imidazol-2-yl & 1.732 & 3.297 & 0.5916 & 3.524 \\
\hline & & $1.404-2.137$ & $2.318-4.688$ & $0.3341-1.047$ & $3.049-4.072$ \\
\hline & Mefloquine & 1.385 & 2.834 & 0.8176 & 2.831 \\
\hline & & $1.233-1.556$ & $2.156-3.726$ & $0.3970-1.684$ & $1.781-4.500$ \\
\hline & Doxorubicin & 0.01 & 0.265 & 0.02 & 0.23 \\
\hline & & $0.01-0.02$ & $(0.17-0.305)$ & $0.01-0.02$ & $0.19-0.25$ \\
\hline
\end{tabular}

${ }^{a}$ Data are presented as $I_{50}$ values, with $95 \%$ confidence intervals obtained by nonlinear regression for all cell lines leukemia (HL-60), ovarium (OVCAR-8), nervous system (SF-295), colon (HCT-8) from three independent experiments. Mefloquine (MQ) was used as positive control. The trials were performed in triplicate. $\mathrm{nd}$, not determined; $\mathrm{IC}_{50}$, concentrations that induce $50 \%$ inhibition of cell growth in $\mu \mathrm{g} / \mathrm{mL}$.

\section{Cell membrane disruption}

These tests were performed in 96-well plates using a $2 \%$ mouse erythrocyte suspension in $0.85 \% \mathrm{NaCl}$ solution containing $10 \mathrm{~mm} \mathrm{CaCl}$ (12). The compounds $\mathbf{1 b - e , ~} \mathbf{1 k}$, 2c, and $M Q$ were diluted as mentioned above and tested at a concentration of $250 \mu \mathrm{g} / \mathrm{mL}$. After incubation at room temperature for $30 \mathrm{~min}$, centrifugation, and removal of the supernatant, the released hemoglobin was measured by spectrophotometry at $540 \mathrm{~nm}$. DMSO was used as a negative control and Triton-X-100 (1\%) as a positive control. After incubation at room temperature for $1 \mathrm{~h}$, centrifugation, and removal of the supernatant, the released hemoglobin was measured by visible spectrophotometry at $\lambda=540 \mathrm{~nm}$. $\mathrm{EC}_{50}$ is the calculated effective concentration that induced lysis on 50\% that of the Triton-X-100.

\section{Results and Discussion}

\section{Chemistry}

In previous studies, we reported the synthesis of compounds, 1-3, from racemic erythro mefloquine and appropriate arenealdehydes (Scheme 1), and their antimycobacterial evaluation against Mycobacterium tuberculosis $\mathrm{H}_{37} \mathrm{R}_{v}$ and resistant strains $(2,3)$.

The reactions between the racemic erythro mefloquine [stereochemistry: $\left.\left(\mathrm{R}^{*}\right)-\mathrm{C} 9,\left(\mathrm{~S}^{*}\right)-\mathrm{C} 10\right]$ and arenealdehydes do not lead to changes of the stereochemistries at C-9 and C-10, but do generate new chiral center at the carbonyl center and at the piperidinyl nitrogen. The NMR data for the compounds studied here indicated the presence of a very major if not a sole stereoisomer, after initial work-up. Crystalline solids, generated for crystallographic studies by slow recrystallization from $\mathrm{EtOH}$, were found to be racemic mixtures having $\left(\mathrm{R}^{*}\right)-\mathrm{C} 9,\left(\mathrm{~S}^{*}\right)-\mathrm{C} 10,\left(\mathrm{~S}^{*}\right)-\mathrm{C}$ (carbonyl), and $\left(\mathrm{R}^{*}\right) \mathrm{N}$ (piperidinyl) stereochemistries.

\section{Cytotoxicity against cancer cell lines}

Compounds $\mathbf{1 a - s}, \mathbf{2 a}-\mathbf{c}, \mathbf{3}$, and $M Q$ were initially tested in vitro against three cancer cells at a concentration of $25 \mu \mathrm{g} / \mathrm{mL}$, using the MTT assay (Table 1) (11). According to their growth inhibition (Gl) in at least one of the cell line, the compounds were classified as active $(95<\mathrm{Gl}<100)$, moderately active $(70<\mathrm{Gl}<90)$, or inactive $(\mathrm{Gl}<50 \%)$. Compounds $\mathbf{1 b}-\mathbf{c}, \mathbf{1 e}, \mathbf{1 k}, \mathbf{2 c}$, and $M Q$ were thus classified as being active and derivative $\mathbf{1 d}$ as moderately active, while all the other compounds were inactive against all cancer cell lines at $25 \mu \mathrm{g} / \mathrm{mL}$.

The active compounds were selected for in vitro anticancer activity evaluations against four human cancer cell lines (HCT-8, OVCAR-8, HL-60, and SF-295) using the MTT assay (Table 2) (11). The concentrations that induced $50 \%$ inhibition of cell growth $\left(\mathrm{I}_{50}\right)$ in $\mu \mathrm{g} / \mathrm{mL}$ are presented in Table 2. None of the compounds was able to disrupt the cell membrane integrity of erythrocytes in the mouse model (data not shown) (12).

The results in Table 2 clearly indicate that compounds 1b-e, 1k, 2c, and $M Q$ exhibited good cytotoxic activity against the four cancer cell lines. All four compounds, $\mathbf{1 b}-\mathbf{e}$, possess strong electron-releasing groups, namely 2- $\mathrm{HO}, 2-$ $\mathrm{MeO}, 4-\mathrm{MeO}$, and 3,4-( $\mathrm{MeO})_{2}$, respectively. As compound 1a and compounds with electron-withdrawing substituents, 
Figure 1: (A) Atom arrangements and numbering scheme for compound 2c. Intramolecular hydrogen bonds are drawn as dashed lines. (B) Two views of the conformation of $\mathbf{2 c}$ : colors: carbon gray; oxygen red; nitrogen blue; fluorine green. Hydrogen atoms have been omitted.
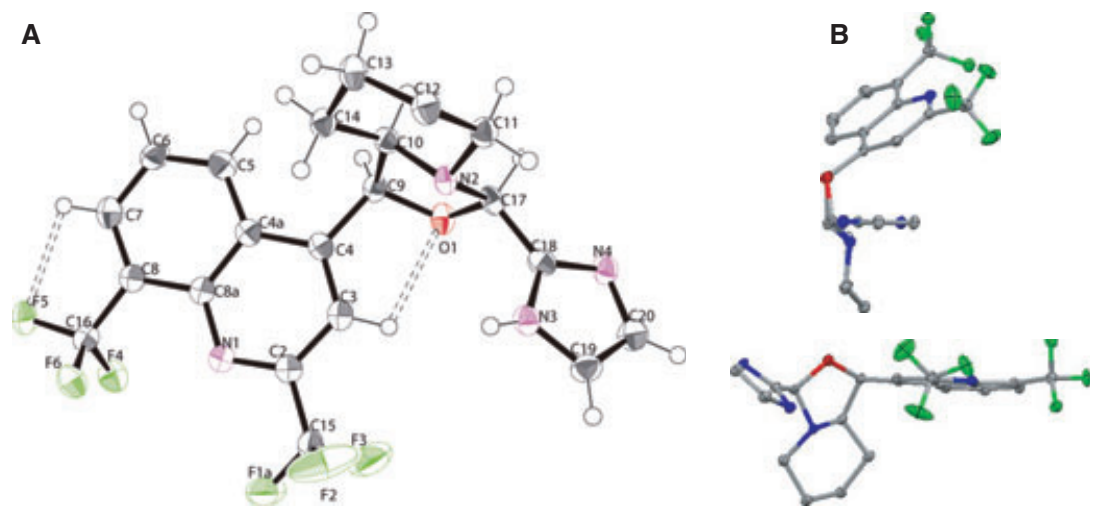

such as nitro and halo, were generally inactive, this strongly indicates the importance of electron-releasing substituents in the phenyl ring for activity. However, it is of interest that neither $\mathbf{1 f}$ (with 3,4,5-(MeO) 3 substitution) nor $\mathbf{1 g}$ (with a 3EtO substituent) were active in the initial testing, see Table 1. This suggests that steric effects are playing some role in the activity too. Of all the compounds containing halogen substituents, compound $\mathbf{1 k}$ was the only one to show activity, with $\mathrm{IC}_{50}(\mu \mathrm{g} / \mathrm{mL})$ values of $2.957,4.074,0.8873$, and 3.524, against the cancer cell lines: HCT-8, OVCAR-8, HL-60, and SF-295, respectively.

Among the three compounds derived from heteroarenealdehydes, $\mathbf{2 a - 2 c}$, only the imidazole derivative, $\mathbf{2 c}$, was active. The imidazole ring is an electron-rich ring and again supports the importance of electron release for activity. The non-activity of the nitrofuranyl $(\mathbf{2} \mathbf{a})$ and nitrothienyl $(\mathbf{2} \mathbf{b})$ derivatives follows on from the non-activities of the nitrophenyl derivatives, 1q-1s.

Currently, $\mathrm{MQ}$ combined with other drugs is in phase I factorial trial for the treatment of patients with glioblastoma. In this way, it is interesting to highlight that an improved cytotoxicity was observed for compound $\mathbf{1 b}$, against the glioblastoma cell line SF-295. This result displays the relevance of the proposed molecular modification for the development of new anticancer agents.

The molecular arrangement of the active imidazole derivative, 2c, was determined in this study by $\mathrm{X}$-ray crystallography, see Figure 1A. The non-chiral space group, P21/c, indicates that both enantiomers of 2c are present in the single crystal examined. The chiral centers at C9, C10, C17, and N2 (crystallographic numbering system) are $\left(R^{*}\right),\left(S^{*}\right),\left(S^{*}\right)$, and $\left(R^{*}\right)$, respectively. Figure 1A shows the atom arrangements in the $(R),(S),(S),(R)$-enantiomer. The bond angles and bond lengths are all in the expected regions. The piperidine ring has a chair shape, while the oxazolidine ring has an envelope shape with a flap at the nitrogen atom. Two views of the conformation of the molecule can be seen in Figure 1B. As previously found with active $\mathbf{1 b}$ (19), as well as inactive 1a (20), 1f (2), and 1q-1s (20), both the quinoline and aryl rings are on the same side of the best plane through the combined oxazolidine and piperidine rings, thus giving a crude ' $F$ ' shape arrangement. Furthermore, the quinoline and aryl rings are spread like opened butterfly wings. While there are

Table 3: Interplanar angles

\begin{tabular}{|c|c|c|c|c|}
\hline \multirow[b]{2}{*}{$\begin{array}{l}\text { Compound } \\
\text { [Reference] }\end{array}$} & \multicolumn{3}{|c|}{ Angles between planes ${ }^{a}$} & \multirow{2}{*}{$\begin{array}{l}\text { Active or } \\
\text { not as } \\
\text { antitumor } \\
\text { agents }\end{array}$} \\
\hline & $\begin{array}{l}\text { Heterocycles/ } \\
\text { phenyl }\end{array}$ & $\begin{array}{l}\text { Phenyl/ } \\
\text { quinoline }\end{array}$ & $\begin{array}{l}\text { Heterocycles/ } \\
\text { quinoline }\end{array}$ & \\
\hline $\mathbf{1 b}(13-18)$ & $59.7^{\circ}$ & $17.4^{\circ}$ & $78.5^{\circ}$ & Active \\
\hline $2 c^{\mathrm{b}, \mathrm{c}}$ & $76.2^{\circ}$ & $40.3^{\circ}$ & $71.1^{\circ}$ & Active \\
\hline $3(2)$ & $61.9^{\circ}$ & $52.8^{\circ}$ & $77.1^{\circ}$ & $\begin{array}{l}\text { Non- } \\
\text { active }\end{array}$ \\
\hline $1 a$ & $75.9^{\circ}$ & $38.5^{\circ}$ & $82.1^{\circ}$ & $\begin{array}{l}\text { Non- } \\
\text { active }\end{array}$ \\
\hline $1 q$ & $72.0^{\circ}$ & $38.4^{\circ}$ & $84.0^{\circ}$ & $\begin{array}{l}\text { Non- } \\
\text { active }\end{array}$ \\
\hline $1 \mathrm{r}$ & $80.2^{\circ}$ & $24.3^{\circ}$ & $81.2^{\circ}$ & $\begin{array}{l}\text { Non- } \\
\text { active }\end{array}$ \\
\hline 1s & $87.2^{\circ}$ & $14.1^{\circ}$ & $78.9^{\circ}$ & $\begin{array}{l}\text { Non- } \\
\text { active }\end{array}$ \\
\hline
\end{tabular}

aHeterocycles = fused oxazolidine and piperidine rings.

'This study.

${ }^{\circ}$ Crystal data collected at $120(2) \mathrm{K}$, colourless crystal: $0.3 \times 0.06 \times 0.04 \mathrm{~mm}$. Formula: $\mathrm{C}_{21} \mathrm{H}_{16} \mathrm{~F}_{6} \mathrm{~N}_{4} \mathrm{O}, \quad \mathrm{M}=454.38$; monoclinic, $\mathrm{P} 21 / \mathrm{c} ; \mathrm{a}=5.1701(4) \mathrm{A}, \mathrm{b}=18.011(2) \mathrm{A}, \quad \beta=93.047$ $(7)^{\circ}, c=21.008(3) \AA, Z=4, V=1953.5(4) \AA(3), 4454$ independent reflections $[R($ int $)=0.1055], 2526$ observed reflections $[\mathrm{I}>2 \sigma(\mathrm{l})]$ : parameters refined 4454 ; number of restraints $0 ; \mathrm{R}(\mathrm{F})$ 0.090(obs data), largest diff.peak $0.66 \mathrm{e}^{-3}$. Atomic coordinates, bond lengths, angles and thermal parameters have been deposited at the Cambridge Crystallographic Data Centre, deposition number 927346. 
differences in the interplanar angles in each case as shown in Table 3, there is no apparent correlation between molecular conformations and activity. The major intermolecular interactions in 2c are classical $\mathrm{N}_{3}-\mathrm{HN}_{3}-\mathrm{N}_{4}$ hydrogen bonds, which are augmented by weak $\mathrm{C}-\mathrm{F}-\pi$ interactions to form chains of molecules.

Contrasting with the good anticancer activity of $M Q$, 4-bromo-2,8-di(trifluoromethyl)quinolone was found to exhibit no anticancer activity (data not shown). This apparently indicates that the 2-piperidinylmethanol moiety is an important privileged structure for the anticancer activity.

\section{Conclusion}

In this work, the first to evaluate $\mathrm{MQ}$ derivatives as antitumor agents, a series of $23 \mathrm{MQ}$-oxazolidine derivatives were evaluated for their activity against 3-5 cancer cell lines with good cytotoxicities $\left(\mathrm{IC}_{50}\right.$ ranging from 0.59 to $4.79 \mu \mathrm{g} / \mathrm{mL}$ ). Compounds with aryl groups having strong electron-releasing substituents, such as $\mathrm{HO}$ and $\mathrm{MeO}$, or electron-rich heteroaryl groups, for example imidazol-2-yl, can be considered as useful leads for the rational design of new antitumor compounds, as these are more active than $M Q$ against ovarium (OVCAR-8) (1d), leukemia (HL-60), and glioblastoma (SF-295) cells. The MQ-oxazolidine derivatives are considered to be useful leads for the rational design of new antitumor agents. Further studies to obtain structure-activity relationships and the elucidation of the mechanisms of cytotoxicity presented by these compounds are in progress.

\section{Acknowledgments}

The authors gratefully acknowledge FIOCRUZ, Farmanguinhos, CAPES, CNPq, and FUNCAP (Fundação Cearense de Apoio ao Desenvolvimento Científico e Tecnológico) for the support.

\section{References}

1. Kunin C.M., Ellis W.Y. (2000) Antimicrobial activities of mefloquine and a series of related compounds. Antimicrob Agents Chemother;44:848-852.

2. Gonçalves R.S.B., Kaiser C.R., Lourenço M.C.S., Bezerra F.A.F.M., de Souza M.V.N., Wardell J.L., Wardell S.M.S.V., Henriques M.G.M.O., Costa T. (2012) Mefloquine oxazolidine derivatives, derived from mefloquine and arenecarbaldehydes: in vitro activity including against the multidrug-resistant tuberculosis strain T113. Bioorg Med Chem;20:243-248.

3. Gonçalves R.S.B., Kaiser C.R., Lourenço M.C.S., de Souza M.V.N., Wardell J.L., Wardell S.M.S.V., da Silva A.D. (2010) Synthesis and antitubercular activity of new mefloquine-oxazolidine derivatives. Eur $J$ Med Chem;45:6095-6100.

4. Bermudez L.E., Kolonoski P., Wu M., Aralar P.A., Inderlied C.B., Young L.S. (1999) Mefloquine is active in vitro and in vivo against Mycobacterium avium complex. Antimicrob Agents Chemother;43:1870-1874.

5. Carson D.A., Leoni L.M., Cottam H.B., inventors (2003) Regents of the University of California, assignee. Treatment of cancer with mefloquine, its purified enantiomers, and mefloquine analogs. United States patent US 20030216426.

6. Ingram K., Ellis W., Keiser J. (2012) Antischistosomal activities of mefloquine-related arylmethanols. Antimicrob Agents Chemother;56:3207-3215.

7. Schrattenholz A., inventor (2005) Proteosys A.-G., Germany, assignee. Mefloquine, nelfinavir and saquinavir as novel agents for neurodegenerative and (neuro-) inflammatory diseases. United States patent US 2005670648.

8. Seo J.B., Sun H.M., Choi S.S., Park D.Y., Park J.Y., Choi E.U., Jung J.Y., Shin D.S., Lee T.G., inventors (2012) BRNScience Co., Ltd., S. Korea, assignee. Mefloquine for preventing and treating bone disease. Republic Korean patent KR 2012045123.

9. Sharma N., Thomas S., Golden E.B., Hofman F.M., Chen T.C., Petasis N.A., Schonthal A.H., Louie S.G. (2012) Inhibition of autophagy and induction of breast cancer cell death by mefloquine, an antimalarial agent. Cancer Lett;326:143-154.

10. Shin J.H., Park S.J., Jo Y.K., Kim E.S., Kang H., Park J.H., Lee E.H., Cho D.H. (2012) Suppression of autophagy exacerbates mefloquine-mediated cell death. Neurosci Lett;515:162-167.

11. Ahmed S.A., Gogal R.M. Jr, Walsh J.E. (1994) A new rapid and simple non-radioactive assay to monitor and determine the proliferation of lymphocytes: an alternative to $[3 \mathrm{H}]$ thymidine incorporation assay. J Immunol Methods; 170:211-224.

12. Sharma P., Sharma J.D. (2001) In vitro hemolysis of human erythrocytes - By plant extracts with antiplasmodial activity. J Ethnopharmacol;74:239-243.

13. Hooft R.W.W. (1998) COLLECT, Data Collection Software. Delft, The Netherlands: Nonius BV.

14. Sheldrick G.M. (2007) SADABS Version 2007/2. Madison, Wisconsin, USA: Bruker AXS Inc.

15. Otwinowski Z., Minor W. Jr. (1997) Processing of X-ray diffraction data collected in oscillation mode. In: Carter C.W., Sweet R.M., editors. Methods in Enzymology, Vol. 276: Macromolecular Crystallography, Part A. New York: Academic Press; p. 307-326.

16. Farrugia L.J. (1997) ORTEP-3 for Windows - a version of ORTEP-III with a Graphical User Interface (GUI). J Appl Crystallogr;30:565.

17. Sheldrick G.M. (2008) A short history of SHELX. Acta Crystallogr A;64:112-122.

18. Spek A.L. (2003) Single-crystal structure validation with the program PLATON. J Appl Crystallogr;36:7-13. 
623

19. Gonçalves R.S.B., Kaiser C.R., de Souza M.V.N., Wardell J.L., Wardell S.M.S.V., Tiekink E.R.T. (2011) 2-\{1-[2,8-Bis(trifluoromethyl)quinolin-4-yl]-3,5,6,7,8,8ahexahydro-1H-1,3-oxazolo[3,4-a]pyridin-3-yl\} phenol. Acta Cryst;E67:01656-01657.

20. Gonçalves R.S.B., Kaiser C.R., de Souza M.V.N., Wardell J.L., Wardell S.M.S.V., Howie R.A. (2011) Structures of 4-\{3-(X-phenyl)perhydro-1,3-oxazolo[3,4a]pyridin-1-yl\}-2,8-bis(trifluoromethyl)quinolines $(X=\mathrm{H}$, $2-\mathrm{O}_{2} \mathrm{~N}, 3-\mathrm{O}_{2} \mathrm{~N}$ and $4-\mathrm{O}_{2} \mathrm{~N}$ ), derived from mefloquine. $\mathrm{Z}$ Krist;226:793-803.
Mefloquine Derivatives as New Class of Anticancer Agents

\section{Notes}

${ }^{a}$ Cancer.org [homepage on the Internet]. American Cancer Society. Available from: http:www.cancer.org/. Accessed: February 01, 2013.

${ }^{b}$ Global Health Observatory [homepage on the Internet]. World Health Organization; c2013. Available from: http:// www.who.int/gho/ncd/mortality_morbidity/cancer/en/index. html. Accessed: February 13, 2013. 